\title{
An Approach To Determining The Market For Academic Positions: Application To The Discipline Of Agricultural Economics
}

Terence Farrell, Washington State University

Ken Casavant, (Email: casavantk@wsu.edu), Washington State University

Eric Jessup, (Email: eric_jessup@wsu.edu), Washington State University

\begin{abstract}
This paper presents relevant issues in choice of an academic career in the chosen discipline of each student. The analytical model, applied to agricultural economics, is a supply/demand construct.
\end{abstract}

\section{INTRODUCTION}

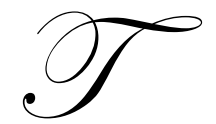

he purpose of this paper is to present issues that are relevant to pursuing an academic career in the chosen discipline of each student. The application will be a general case study of agricultural economics. The analytical model will be used to evaluate options for Ph.D. graduates in a supply and demand context. The first issue presented is a review of demand for economics instructors in academic settings. The next section focuses on "change" within academic institutions including the role of Internet courses, funding and tenure, all of which may affect the supply (quality of life and costs) of the chosen discipline. Section three describes the skill sets required with the academic profession, agricultural economics in this case study, with particular emphasis on positioning oneself for an academic career. The audience envisaged for this paper and its conceptual model include all students considering an academic career or in this application, agricultural economics graduate students and their mentors.

Huffman and Orazem (1985) were among the first to apply a demand and supply construct to the market for $\mathrm{PhD}$. graduates. Their demand and supply variables were primarily related to the level of income from assistantships and assistant professor wage levels as well as post doctorial expenditures on agricultural programs and institutions. Their analytical model was centered on numerical values, which limits the scope of such models to variables that are well defined numerically. In this article we employ a demand and supply conceptual framework to include information that is less definitive.

\section{ACADEME, BUSINESS OR BOTH?}

Some students in agricultural economics cling to an expectation of finding academic employment with the profession upon graduation from a Ph.D program. This expectation is realistic; however the number of academic positions (demand) is decreasing in the United States. Alternatively, the number of business related positions for agricultural economists is rising. Some students are attracted by the more lucrative appeal of business careers. These career options are not mutually exclusive as non-academic positions may also contain aspects of teaching, research, extension and other scholarly activity. In some agricultural economics departments, adjunct professors who work for government or agribusiness present business classes to enhance academic extension and business relations. In order to make an informed decision as to a desirable career plan it is important to understand the options, rewards and expectations associated with each type of position.

Entry into academe is usually sought after completing the Ph.D program, with attendant advantages and disadvantages. The advantage for this timing is that graduate students can migrate into tenure track positions without the large investment of time required to re-learn theory, quantitative methods and the workings of academic 
departments if they return after serving in non-academic positions. The disadvantage is that the new scholar can only theorize about and model the complexity of government policy or businesses and their functions and environments. Economist positions in government or extension typically provide he prospective tenure candidate with opportunities to publish. Thus, government employees are more competitive relative to business economists when applying for academic positions later in their careers. Careers where employees are strictly focused on the day-to-day management and operations of a business are less complementary with academic acceptance criteria and the potential career in academe may suffer.

\section{DEMAND FOR ACADEMIC INSTRUCTORS}

The market for $\mathrm{Ph} . \mathrm{D}$ graduates is linked to higher education demand from new undergraduate students. Weldon, Covinton, Long and Connor (1999) provide a five year insight into "who the future students will be." Weldon, et al estimated that undergraduate enrollment in "on campus" degree programs would decrease by nearly four percent during the early 2000s. A ten percent decline in "on campus" students was expected for students with agricultural backgrounds. Students from farm backgrounds were more likely to appear among the "off campus" student group that was expected to increase by 11 percent. Department chairs, who were surveyed by Weldon, et al, expected an increase of eight new programs in agribusiness and three new programs in resource economics at the Master's level. Four new PH.D programs in resource economics, international trade, farm management, and agribusiness management were also expected during the next ten years. The department head at one institution announced that the institution would drop its Ph.D program in agricultural economics. Twelve departments of agricultural economics offer classes completely off campus. Twenty departments were expecting to deliver the off campus courses via the web and 19 were expected to utilize interactive video methods. These data clearly indicate the methods of instruction will likely change.

The increase in web-based teaching is likely to have a negative effect on the demand for instructors. Theoretically, courses may be professionally produced and replayed to students each year without the continuing need for an instructor. Projecting this trend, the current market for instructors may evolve into a market for graders and on line teaching assistants. Furthermore, academic institutions may offer on line courses by professors from universities who are considered to be world leaders in their field in lieu of local faculty. Strategies such as this may reduce the need for departments to cover the full spectrum of fields within their discipline allowing the department to become more specialized in niche areas. The incentive for departments to pursue this route may arise from further budgetary constraints: a common demand shifter.

The literature on the domination of the Internet over classroom teaching remains inconclusive. An article by Bonwell (1999) describes how to use active learning to enhance lectures. The level of communication between the lecturer and the student is discussed in some detail, particularly differences between teaching and learning styles. Monitoring performance and providing feedback assists the students' understanding of material and appears to be vital in teaching difficult material. Collegiality between faculty and students is thus sacrificed in some Internet classes (, demand is shifted by tastes and preferences). The use of Internet teaching or totally "produced" video lectures or classes may need to be refined further before the more challenging classes gravitate toward the web domain. Nevertheless candidates interested in teaching careers should endeavor to expand their skill sets to include web-based instruction.

\section{RISING COST OF TUITION}

A significant source of university funding is the tuition that students pay in return for an education. Increasing tuition fees force students of marginal incomes to be highly selective about where they will spend their tuition dollars. This decision may be based upon the return expected in terms of prospects at the completion of their studies. The rising cost of tuition may force marginal income students into the work force earlier in life. These same individuals may reconsider university education when their incomes increase after some time in the workforce. Rising tuition cost may thus produce a larger age gap between students, requiring a greater diversity in teaching styles and different lecturer-student interactions. A more mature student population is likely to be increasingly challenging according to its knowledge of business or level of experience in government. 


\section{NEW DEMAND TYPES}

Hyde and Lovejoy (1999) reported that 68 percent of economics departments with the United States were expecting to replace staff in 2000 due to retirement. However, this number may have been too high as student numbers in economics departments have been declining and many lecturing positions were not replaced as faculty left or retired (Sanderson et al, 2000). Professors are now less likely to retire completely. More are choosing to continue their research in one form or another. Departments retain these eminent professors in some capacity on faculty as they invariably increase the department's publications record and act as mentors to new faculty. Their former teaching functions may be delegated to part-time instructors.

The trend toward part-time teaching faculty is increasing due to the relatively low cost of hiring temporary teaching staff relative to tenured faculty. Leatherman (2000) showed that 40 percent of staff at four-year academic institutions were part-timers in 1997, relative to 35 percent of staff at two year institutions. The transition of $\mathrm{PhD}$ graduates to two-year institutions reflects the reduction in teaching positions in four-year institutions. This transition also implies that tenure at two-year institution was deemed superior to semester-by-semester contracts at four-year institutions.

Hyde and Lovejoy (1999) further explored the options available to agricultural economist to work in colleges and universities outside of the land grant system. These authors show that "other" colleges are heavily focused on teaching and that new economists are more likely to be teaching agribusiness in business schools. They suggest that economists who like teaching should focus on studying economic theory and take more business courses to win placement in two-year colleges.

\section{ISSUES OF TENURE}

McPherson and Schapiro (1999) argue that tenure survives in many research institutions. Several incidences have occurred where faculty have agreed to place new employees on contracts rather than provide tenure. However, results of the study on the percentage of full time faculty who are tenured reveal a one percent decrease in the research universities between 1988 and 1996 and a one percent increase in the other institutions including doctoral universities, comprehensive universities and liberal arts colleges. These results include tenured professors who took advantage of the end of mandatory retirement in 1994; thus, they may inflate the numbers slightly. McPherson and Schapiro found that the advantage of tenure was that it provided a "cottage industry" approach to education; however, they also cautioned that the opportunity cost of this type of industry was rising and increases in technology and communication will play a significant role in deciding whether the tenure system will predominate in future years. Their final concern was to make the reader aware that tenure need not be considered as an "all or nothing" notion. Hence variations of the current tenure conditions may persist in the future, particularly for the more able candidates.

According to the American Faculty Poll (Sanderson, et al 2000) 37 percent of faculty in four year institutions reported that there had been some effort on behalf of the institution to modify or eliminate the tenure system at their institution. Fifty five percent of all faculty surveyed favored tenure retention relative to 41 percent who favored some modification to the tenure system. In an effort to limit the number of faculty members with tenure, "some faculty members saw the hiring of more part time, adjunct and non tenure track positions as an indirect way of tackling the problem." Apparently this method of tenure reduction continues with more part time teaching positions being made available relative to fulltime positions (Sanderson et al 2000).

Leatherman (2000) quotes John M. Hammang, director of special projects for the American Association of State Colleges and Universities, as saying "It's not unusual to respond to increasing enrollments with part time employment". The same response could have been presented with respect to decreasing enrollments. This raises the question of when is it a good time to increase full time employment or tenure track positions. One might suggest that a suitable time is when enrollments are projected to increase. Demand for degrees in economics is falling and there is considerable uncertainty regarding the role of the Internet as a teaching tool; thus, new faculty may have to survive on short-term contracts rather than hold out for tenure in the current environment. 


\section{SUPPLY OF AGRICULTURAL ECONOMISTS}

Siegried and Stock (1999) examined the labor market for new Ph.D economists. In their paper these authors reviewed the academic market and the alternative markets for criteria including wages, satisfaction with position and relevance of training toward career choice. The average age of new Ph.D graduates was found to be 32 and the time required to complete a Ph.D increased from 5.7 years in 1977 to 6.8 years in 1996.

There are differences and analogies between the job market for economists and other disciplines (Freeman, 1999). Economists are more likely to move into other markets if the demand for economists falls. Economists are apparently welcomed in business schools, law schools, medical schools, government and schools of public administration as faculty. The majority of new Ph.D degrees in economics are awarded to "non U.S. citizens, half of whom remain in the United States for their first appointment" which is likely to be in business rather than academe.

The length of time required to complete a Ph.D imposes a constraint on the future supply of graduates. Hansen (1999) found that more research-oriented faculty in academe might now be insisting on higher standards of performance in Ph.D work. An alternative argument may be that Ph.D students are being used to fill gaps in teaching and research positions, thus extending completion times. It is obviously in the department's financial interest to extend training periods for Ph.D students who exhibit strong teaching or research abilities. The opportunity cost of students remaining in school for an additional year is in line with the average commencing salaries of new graduates, which is approximately $\$ 70,000$. Some students might trade-off the cost of more years in school in return for a higher probability of securing an academic position once they graduate.

\section{SUPPLY CHARACTERISTICS}

A new Ph.D student should endeavor to meet certain criteria, in the areas of publishing, teaching and grantsmanship. Shively et al suggest that the new graduate should not appear in an interview posing to be a wellqualified student. Rather, the candidate should give the appearance of a well-qualified junior faculty member. Potential faculty members give the appearance of being a team player, with several publications in print or at the reviewer's desk. A well refined Ph.D manuscript alone does not weigh highly in the minds of other faculty.

Potential new faculty will have demonstrated teaching experience at a level where the student instructor is responsible for preparing the material, teaching, grading and providing feedback. Where possible, this teaching should be documented and preferable evaluated by faculty members. Shively, et al argue that teaching is a weakness in new faculty particularly those from research institutions. Unfortunately, some Ph.D research programs do not allow students enough time to entertain any notion of teaching. Nevertheless students should seek opportunities where they arise.

The third area of skill described by Shively et al is grantsmanship. They claim this is an area of scholarship that is often over looked. New faculty are required to raise money to fund "research graduate student research assistants and in some cases, part of the faculty member's own salary". Graduate students should not be deterred from writing funding submissions simply because students are not encouraged to apply for grants. Many proposals do not get written because faculty are short on time and therefore avoid projects that are only tangentially related to their personal research interests.

George Ladd (1991) produced a paper titled "thoughts on building an academic career." In his paper Ladd claims that there are topics other than economics, statistics and mathematics that are important to an economics career. Among Ladd's criteria is the principle that "you should enjoy what you do." To make ends meet, Ladd suggests that researchers should have a portfolio of "safe projects" intertwined with some "risky projects." The risky projects should have a high pay-off to make them worthwhile. Teaching may be included in the portfolio. He suggests that the key idea behind being productive is to be working at the margins of knowledge where the greatest comparative advantage occurs. Comparative advantage includes economic skills as well as "the type of person you are." An economist should also present the capacity for surprise as well as be a skeptic. Intuition, deduction and induction are 
the three mental processes that should be used under limited conditions. Ladd claims, "we must not trust intuition too far because it is fallible and it does not prove anything about the real world."

The role and tools of instructors and researchers (supply characteristics) are set to change as the student population ages and the factors that impact upon student enrollments proceed. The decision whether to focus on a teaching/research career or the alternative business/government career is best made earlier in the academic program as students can gain a considerable advantage by making sure that they have all the "requirements" for their preferred career satisfied in their program.

\section{FINAL THOUGHTS}

A brief test of a supply-demand conceptual framework for evaluating the pursuit of an academic career, applied to a case study of agricultural economics, was the focus of this paper. It is evident that many factors influence a career decision when entering academe, on both the supply and demand sides of the market. Some areas such as agribusiness appear to be growing in student demand whereas traditional economics appears to be in decline. The number of academic positions available within the U.S. market is governed by the demand shifters of student enrolments and government funding of research and extension. Rising tuition costs and lower government spending on agricultural research in four-year institutions leads to the conclusion that employment for many graduates of agricultural economics programs will be in non-traditional areas. Areas that show an increase in demand are two-year colleges and departments in four-year colleges such as business and marketing.

The nature of teaching is likely to change with the increased use of the Internet, the aging of student and tuition increases. New Ph.D graduates should prepare (the supply side) to be good academics rather than good graduate students if they intend to pursue a career in teaching and research. This involves more teaching, grant writing and more paper presentations relative to the traditional focus on research alone. More positions for adjunct professions may become available for those who want the best of both the business and academic worlds later in their professions.

The demand/supply framework provides a holistic account of the environment facing Ph.D. graduates. This construct can be fitted productively for any academic discipline.

\section{REFERENCES}

1. Boland, Michael and Scott Daniel. 1999. Training Agricultural Economists for the Private Sector: Are We Meeting Their Needs? Review of Agricultural Economics, 21 (2): 319-330.

2. Bonwell, Charles C. 1999. Using Active Learning to Enhance Lectures. Review of Agricultural Economics, 21 (2): 542-550.

3. Clotfelter, Charles T. 1999. The Familiar but Curious Economics of Higher Education: Introduction to a Symposium. Journal of Economics Perspectives, 13 (1);3-12.

4. Freeman, Richard B. 1999. It's Better Being an Economist (But Don't Tell Anyone). Journal of Economic Perspectives, 13 (3); 139-145.

5. Goldin, Claudia and Lawrence F. Katz. 1999. The Shaping of Higher Education: the Formative Years in the United States, 1890-1990. Journal of Economic Perspectives, 13 (1); 37-62.

6. Hansen, W. Lee. 1999. The Link from Graduate Education in Economics to the Labor Market. Journal of Economic Perspectives, 13 (3); 147-151.

7. Huffman, W. E. and Orazem, P. 1985 An econometric model of the market for new Ph.D.'s in Agricultural Economics in the United States', American Journal of Agricultural Economics, 67 (December) pp. 1207-14.

8. Hyde, Jeffrey and Stephen B. Lovejoy. 1999. Academic Opportunities Outside the Land Grant System; Exploring a Niche Market for Agricultural Economics Ph.D Students. Review of Agricultural Economics, Vol. 21 (1): 140-147.

9. Ladd, George W. 1991. Thoughts on Building an Academic Career. Western Journal of Agricultural Economics, 16 (1): 1-10. 
10. Leatherman, Courtney. 2000. Part-timers Continue to Replace full Timers on College Faculties. The Chronicle of Higher Education. January $28^{\text {th }}$.

11. McPherson, Michael S. and Morton Owen Schapiro. 1999. Tenure Issues in Higher Education. Journal of Economic Perspectives, 13 (1): 85-98.

12. Sanderson, Allen, Voon Chin Phua, and David Herda. 2000. The American Faculty Poll. TIAA-CREF New York, New York and National Opinion Research Center, Chicago, Illinois.

13. Shively, Gerald, Richard Woodward, and Denise Stanley. 1999. Strategy and Etiquette for Graduate Students Entering the Academic Job Market. Review of Agricultural Economics, 21 (2): 513-526.

14. Siegfried John J. and Wendy A. Stock. 1999. The Labor Market for New Ph.D. Economists. Journal of Economic Perspectives. 13 (3): 115-134.

15. Weldon, Richard N., Bea Covington, Burl F. Long, and Richard Larry J. Connor. 1999. Who Will Our Students Be? A Futuristic View. Review of Agricultural Economics, 21 (2):527-541.

16. Winston, Gordon C. 1999. Subsidies, Hierarchy and Peers: The Awkward Economics of Higher Education. Journal of Economic Perspectives, 13 (1); 13-36.

\section{NOTES}

